\title{
KANDUNGAN PROTEIN KASAR, KALSIUM, DAN FOSFOR TEPUNG LIMBAH UDANG SEBAGAI BAHAN PAKAN YANG DIOLAH DENGAN ASAM ASETAT $\left(\mathrm{CH}_{3} \mathrm{COOH}\right)$
}

\author{
Andre R.Y. Wowor*, B. Bagau **, I. Untu ** dan H. Liwe ** \\ Fakultas Peternakan, Universitas Sam Ratulangi Manado, 95115
}

\begin{abstract}
ABSTRAK
Penelitian ini telah dilakukan untuk mengetahui pengaruh penggunaan larutan asam asetat pada pengolahan tepung limbah udang dengan konsentrasi yang berbeda. Limbah udang yang digunakan berupa daging sisa, kulit, kepala, dan bagian lainnya yang tidak dimanfaatkan.Rancangan penelitian yang digunakan yaitu Rancangan Acak Lengkap (RAL), terdiri dari 4 perlakuan dan 4 ulangan. Perlakuan terdiri dari $\mathrm{A} 0=$ aquades tanpa asam asetat, $\mathrm{A} 1=$ asam asetat $5 \%, \mathrm{~A} 2=$ asam asetat $10 \%$, dan $\mathrm{A} 3=$ asam asetat $15 \%$. Variabel yang diukur yaitu kandungan protein kasar, kalsium, dan fosfor. Hasil analisis keragaman menunjukkan bahwa perlakukan memberikan pengaruh nyata $(\mathrm{P}<0.05)$ terhadap protein kasar, kalsium, dan fosfor. Beda Nyata Jujur menunjukkan bahwa perlakukan A2 berbeda nyata lebih tinggi kandungan protein kasarnya dari perlakuan A0, A1, dan A3. Namun secara nyata menurunkan kadar kalsium dan fosfor. Berdasarkan hasil penelitian ini, persentase protein kasar tepung limbah udang yang diolah dengan asam asetat $10 \%$ merupakan perlakuan terbaik dengan kandungan protein kasar sebesar $58.37 \%$, kalsium 2,98\%, dan fosfor $0,98 \%$.
\end{abstract}

Kata Kunci :Limbah udang, asam asetat, protein, kalsium, fosfo

\footnotetext{
*Alumni Fakultas Peternakan Unsrat ** Jurusan Nutrisi dan Makanan Ternak
}

\begin{abstract}
THE EFFECT OF UTILIZATION OF ACETIC ACID ( $\mathrm{CH}_{3} \mathrm{COOH}$ ) SOLUTION IN SHRIMP WASTE MEAL PROCESSING AS A FEED ON CRUDE PROTEIN, CALCIUM AND PHOSPHORUS CONTENT.An experiment was conducted to determine the effect of different level of acetic acid solution in the processing of shrimp waste meal. Shrimp waste material was in the form of leftover meat, skin, head, and other unutilized parts of shrimp. Research was arranged using Completely Randomized Design (CRD) with 4 treatments: $\mathrm{A} 0=$ distilled water without acetic acid solution, $\mathrm{A} 1=5 \%$ acetic acid solution, $\mathrm{A} 2=10 \%$ acetic acid solution, and $\mathrm{A} 3=15 \%$ acetic acid solution. Each treatment was replicated 4 times. Tukey's test was employed to analyze treatment differences. Variable measured were: crude protein, calcium, and phosphorus content of shrimp waste. Research result showed that acetic acid solution level significantly affect protein, calcium, and phosphorus content of shrimp waste. Crude protein content of A2 was significantly $(\mathrm{P}<$ 0.05) higher compared with A0, A1, and A3, but significantly $(\mathrm{P}<0.05)$ reduced calcium and phosphorus content of shrimp waste meal at the higher level. It can be concluded that utilization of $10 \%$ acetic acid solution in shrimp waste meal processing gave the best result with protein content of $56,37 \%$, calcium $2,98 \%$, and phosphorus $0,98 \%$.
\end{abstract}

Keywords :Shrimp waste meal, Acetic acid solution, Protein, Calcium, Phosphorus 


\section{PENDAHULUAN}

Pengunaan bahan pakan berkualitas untuk penyusunan ransum ternak merupakan persyaratan mutlak yang harus dipenuhi.Dewasa ini, komoditas pakan tertentu mengalami masa yang sulit akibat nilai inputnya meningkat sehingga berdampak terhadap tingginya harga ransum.Kondisi ini memerlukan suatu upaya mendapatkan alternatif bahan pakan yang murah, mudah diperoleh, berkualitas baik, serta bersifat nonpangan (Widodo,2000).Pemanfaatan bahan pakan lokal seperti produk perikanan dan hasil ikutannya semaksimal mungkin diharapkan dapat mengurangi biaya ransum.Salah satu diantaranya adalah limbah udang.

Indonesia tercatat sebagai Negara penghasil udang terbesar ketiga di dunia. Setiap tahunnya dihasilkan sekitar 0,08 juta ton dari luas tambak udang 380.000 hektar. Adapun limbah udang yang dihasilkan dari proses pengolahan udang berkisar 30-40 persen dari berat udang (Purwanti dkk, 2001).

Kebutuhan ternak akan protein menjadi salah satu hal yang krusial bagi peternak dewasa ini. Penggunaan sumber protein yang mahal menjadi salah satu kendala yang berdampak pada tingginya biaya produksi.Limbah udang mengandung protein kasar sekitar 25-40 persen, kalsium karbonat 45-50 persen dan kitin 15-20 persen. Selain sebagai sumber yang telah disebutkan, limbah udang sendiri mengandung karotinoid berupa astaxantin yang merupakan pro vitamin A untuk pembentukan warna kulit.Gambaran kandungan protein dan mineral yang cukup tinggi dari limbah udang, dapat dijadikan sebagai pakan alternatif untuk ternak (Muzzarelli dan Joles, 2000).

Kandungan protein kasar yang tinggi dalam kulit udang ini tidak dapat dimanfaatkan secara maksimal karena adanya faktor pembatas dalam kulit udang, yaitu kandungan khitin yang tinggi. Menurut Purwaningsih (2000), kandungan khitin pada kulit udang yaitu 30\% dari bahan keringnya.Protein yang terkandung dalam kulit udang berikatan erat dengan khitin dan kalsium karbonat (dalam ikatan protein-khitin-kalsium karbonat) sehingga dalam penggunaanya pada ternak akan menurun, terutama dalam pencernaan. Dalam kasus yang signifikan, penggunaan kulit udang berpengaruh pada unggas karena tidak mempunyai enzim khitinase pada saluran pencernaanya.

Upaya memaksimalkan potensi protein dalam kulit udang, menghendaki pengolahan terlebih dahulu untuk menurunkan kadar khitinnya. Pengolahan yang tepat dalam mengolah limbah kulit 
udang seperti pengolahan secara kimiawi dengan menggunakan asam diantaranya asam asetat akan memberikan hasil yang tinggi. Sehingga protein yang dihasilkan dapat digunakan secara maksimal.

Penggunaan asam asetat $\left(\mathrm{CH}_{3} \mathrm{COOH}\right)$ pada dasarnya mengacu pada struktur polimer khitin.Pada posisi C kedua di dalam khitin adalah grup asetamido $\left(\mathrm{NHCOCH}_{3}\right)$, dengan demikian terdapat adanya kemungkinan larutnya asetamido dengan asetat. Penggunaan Asam asetat juga berpengaruh pada hilangnya kalsium karbonat menjadi padatan dan gas $\mathrm{CO}_{2}$, dengan asumsi bahwa, asam asetat akan berikatan dengan asetamido sehingga membentuk gugus protein.

\section{MATERI DAN METODE PENELITIAN}

\section{Tempat dan Waktu Penelitian}

Penelitian ini dilaksanakan di Laboratorium Analisis Pakan Jurusan Nutrisi dan Makanan Ternak Fakultas Peternakan Universitas Sam Ratulangi Manado, pada bulan Maret sampai dengan Mei 2014 selama 2 bulan.

\section{Materi Penelitian}

1. Peralatan

$$
\text { Alat yang digunakan dalam }
$$
penelitian ini yaitu topless kaca, saringan, oven, food chopper, kertas alumunium foil, timbangan digital, wadah aluminium, kamera, dan alat tulis menulis.

2. Bahan

Bahan-bahan yang digunakan dalam penelitian yaitu limbah udang segar dan asam asetat pro-analyst (98\%).

\section{Metode Penelitian}

Rancangan Percobaan : Penelitian ini menggunakan Rancangan Acak Lengkap sesuai petunjuk Steel dan Torrie (1995), dengan 4 perlakuan dan 4 ulangan. Perlakuan limbah udang disusun sebagai berikut:

$$
\mathrm{A}_{0}=\text { Perendaman dengan aquades }
$$
tanpa asam asetat

$\mathrm{A}_{1}=$ Perendaman limbah udang dengan larutan asam asetat $5 \%$

$$
\mathrm{A}_{2}=\text { Perendaman limbah udang }
$$
dengan larutan asam asetat $10 \%$

$$
\mathrm{A}_{3}=\text { Perendaman limbah udang }
$$
dengan larutan asam asetat $15 \%$

Model matematis Rancangan Acak Lengkap sebagai berikut:

$$
Y i j=\mu+\alpha i+\varepsilon i j
$$

Keterangan:

Yij = Nilai pengamatan dari perlakuan ke-i dan ulangan ke-j

$\mu \quad=$ Nilai tengah umum

$\alpha \mathrm{i}=$ Pengaruh perlakuan ke-i 
eij = Pengaruh galat yang timbul pada perlakuan

\section{Variabel Penelitian}

1. Protein

2. Kalsium

3. Fosfor

\section{HASIL DAN PEMBAHASAN}

\section{Pengaruh Perlakuan Asam Asetat Terhadap Kandungan Protein Kasar Tepung Limbah Udang}

Penggunaan asam asetat pada pengolahan tepung limbah udang memberikan pengaruh nyata $(\mathrm{P}<0.05)$ terhadap kandungan protein kasar.Hasil uji lanjut Beda Nyata Jujur (BNJ) menunjukkan perlakuan $\mathrm{A}_{2}$ (pengolahan Asam asetat 10\%) menghasilkan kandungan protein kasar yang secara nyata lebih tinggi dibandingkan perlakuan $\mathrm{A}_{0}$, $A_{1}$, dan $A_{3}$.Hal ini menunjukkan bahwa penggunaan larutan asam asetat sampai $10 \%$ dapat menaikkan nilai protein kasar dan merupakan dosis maksimal untuk menghasilkan kandungan protein kasar tepung limbah udang yang optimal, sebab pada perlakuan $\mathrm{A}_{3}$ (Asam asetat 15\%) kandungan protein kasar telah mengalami penurunan, namun masih lebih tinggi dibandingkan dengan tanpa asam asetat dan asam asetat 5\%. (Tabel 1)
Hasil ini sejalan dengan pendapat Poedjiadi (2010) bahwa konsentrasi asam yang tinggi dapat menyebabkan struktur protein menjadi rusak sehingga kandungan protein turun. Menurut Chamidah dan Elita (2002), perendaman dalam larutan asam asetat menyebabkan protein struktural akan mengalami pengembangan (swelling) sehingga struktur koil terbuka. Selanjutnya dijelaskan, konsentrasi larutan asam asetat yang tinggi menyebabkan terjadinya pemutusan ikatan hidrogen dan pembukaan struktur koil kolagen secara berlebih sehingga sebagian asam amino terekstrak dan terlepas dari kolagen dan terbawa ke air buangan, akibatnya kadar protein yang diperoleh lebih rendah. Hasil penelitian ini sejalan dengan yang dilaporkan Mirzah (1990), bahwa bahan kimia dan panas dapat menguraikan ikatan protein dengan mineral pada kulit udang yang akan mudah terdegradasi sehingga meningkatkan kualitas zat-zat makanannya.

Kandungan protein kasar limbah udang yang diolah dengan asam asetat $10 \%$ sebesar $58,37 \%$ setara dengan hasil penelitian Nwanna (2003) dan Mirzah dkk., (2008) sebesar 58.86\% dan 55.63\% sekalipun keduanya melakukan pengolahan limbah udang secara fermentasi. 
Pengaruh Perlakuan Asam Asetat Terhadap Kandungan Kalsium Tepung Limbah Udang

Penggunaan asam asetat pada pengolahan tepung limbah udang memberikan pengaruh nyata terhadap kandungan kalsium $(\mathrm{P}<0,05)$. Hasil Uji Beda Nyata Jujur menunjukkan kandungan kalsium pada perlakuan $\mathrm{A}_{1}$ dan $\mathrm{A}_{2}$ tidak berbeda nyata $(\mathrm{P}>0.05)$. Begitu pula dengan kandungan kalsium pada perlakukan $A_{2}$ dan $A_{3}$ yang tidak berbeda nyata $(\mathrm{P}>0.05)$.Kandungan kalsium $\mathrm{A}_{1}$ berbedanya nyata $(\mathrm{P}<0.05)$ dibandingkan dengan nilai kalsium pada $\mathrm{A}_{2}$ dan $\mathrm{A}_{3}$.Nilai rataan terendah ditunjukkan pada perlakuan $\mathrm{A}_{3}$ dimana nilai rataan kalsium dari tepung limbah udang sebesar 2,36\%. Penurunan kalsium yang signifikan terjadi pada perlakuan $A_{3}$, sedangkan perlakuan $\mathrm{A}_{2}$ dan $\mathrm{A}_{3}$ tidak berbeda nyata $(\mathrm{P}>0.05)$. (Tabel 2)

Konsentrasi yang meningkat dari asam organik dapat merombak dan melarutkan ikatan mineral. Perombakan dan kelarutan ikatan mineral disebabkan oleh ion $\mathrm{H}$, oleh karena itu semua proses yang menyebabkan perubahan konsentrasi ion $\mathrm{H}$, dapat menyebabkan perubahan kecepatan pelarutan mineral. Peningkatan konsentrasi ion $\mathrm{H}$ dimungkinkan oleh makin meningkatnya konsentrasi asam atau pun keadaan yang menyebabkan makin kuatnya disosiasi asam menghasilkan ion $\mathrm{H}$ (Ismangil dan Hanudin, 2005).

Santoso dkk.(2007) menyatakan bahwa pengolahan dengan asam asetat $0,5 \%$ pada udang vannamei meningkatkan kelarutan kalsium hingga 26,33\%. Hal ini sejalan dengan penelitian Idris (2010) yang menyatakan bahwa penggunaan asam asetat $0,5 \%$ sebagai media perebusan pada udang mantis dapat melarutkan kalsium sebanyak 23,26\%. Hayati (2012) menyatakan bahwa penggunaan asam asetat dalam pengolahan dapat melarutkan mineral pada hewan crustacean.Hal ini sejalan dengan penelitian Abun (2009) bahwa pengolahan dengan asam bersifat membengkakkan (swelling) jaringan, sehingga kalsium jadi mudah terurai dan dapat melarutkan kalsium.

\section{Pengaruh Perlakuan Asam Asetat Terhadap Kandungan Fosfor Tepung Limbah Udang}

Dari uji Beda Nyata Jujur (BNJ) menunjukkan perlakuan $\mathrm{A}_{0}$ berbeda nyata $(\mathrm{P}<0.05)$ dengan perlakukan $\mathrm{A}_{2}$, dan $\mathrm{A}_{3}$, sedangkan perlakuan $\mathrm{A}_{0}$ tidak berbeda nyata $(\mathrm{P}>0.05)$ dengan perlakuan $\mathrm{A}_{1}$ Perlakukan $\mathrm{A}_{1}$ tidak berbeda nyata $(\mathrm{P}>0.05)$ dengan $\mathrm{A} 2$, dan perlakuan $\mathrm{A} 3$. (Tabel 3)

Semakin tinggi konsentrasi larutan asam asetat, semakin besar fosfor yang terdegradasi dalam tepung limbah 
udang.Hal ini sejalan dengan pendapat Bastaman (1989), yang menyatakan bahwa komponen mineral dapat dilarutkan dengan menggunakan asam dan menurut Ismangil dan Hanudin (2005), perubahan konsentrasi dapat menyebabkan perubahan kecepatan pelarutan mineral termasuk fosfor.

Santoso dkk.(2008) melaporkan bahwa penggunaan asam asetat $0.5 \%$ pada udang vannamei mempengaruhi kelarutan mineral makro seperti fosfor. Abun (2009) melaporkan bahwa kandungan fosfor terlarut dipengaruhi konsentrasi larutan dan waktu, yang akan mempengaruhi kerja larutan untuk merombak ikatan mineral, namun penggunaan waktu yang lama dapat meningkatkan kandungan fosfor terlarut tetapi peningkatannya tidak berbeda nyata.

Hasil penelitian Idris (2010) menunjukkan pengaruh adanya nyata terhadap kelarutan mineral makro melalui penggunaan asam asetat terhadap udang mantis. Hal ini sejalan dengan pernyataan Sediaoetama (1993) dan Winarno (2008) bahwa kelarutan pada bahan yang melibatkan ikatan hidrogen akan meningkat pada keadaan asam.

\section{KESIMPULAN DAN SARAN}

\section{Kesimpulan}

Persentase protein kasar tepung limbah udang yang diolah dengan asam asetat $10 \%$ merupakan perlakuan terbaik dengan kandungan protein kasar 58,37\%, kalsium $2,98 \%$, dan fosfor $0,98 \%$.

\section{Saran}

1) Pengolahan tepung limbah udang melalui perendaman dengan larutan asam asetat 10 persen dapat dijadikan komoditas bahan pakan sumber protein hewani.

2) Untuk mengetahui pencapaian optimalitas tepung limbah udang, perlu dilakukan uji biologis pada ternak.

\section{DAFTAR PUSTAKA}

Abun.2009. Pengolahan Limbah Udang Windu Secara Kimiawi Dengan $\mathrm{NaOH}$ dan $\mathrm{H}_{2} \mathrm{SO}_{4}$ Terhadap Protein dan Mineral Terlarut. Makalah Ilmiah. Jurusan Nutrisi dan Makanan Ternak, Fakultas Peternakan Universitas Padjajaran.

Bastaman, S. 1989. Studies on Degradation and Extraction of Chitin and Chitosan from Prawn Shell (Nephrops norvegicus).Thesis. The Departement of Mechanical Manufacturing, Aeronautical and Chemical Engineering, Faculty of 
Engineering, The Queen's

University of Belfast.

Chamidah, A. dan Elita Ch. 2002.Pengaruh Pengolahan

Terhadap Kualitas Gelatin Kulit Ikan Hiu.Seminar Nasional PATPI.ISBN : 979-95249-6-2, Malang.

Hayati, A. 2012. Pengaruh Perendaman Asam Organik Terhadap Kelarutan Mineral Kerang Darah (Anadara granosa). Skripsi. Departemen Teknologi Hasil Perairan, Fakultas Perikanan dan Ilmu Kelautan, Institut Pertanian Bogor.

Idris M. 2010. Komposisi Mineral Udang Mantis (Harpiosquilla raphidea) dan Pengaruh perebusan Terhadap Kelarutan Mineral.Skripsi.Fakultas Perikanan dan Ilmu kelatuan, Institut Pertanian Bogor.

Ismangil dan E. Hanudin.2005. Degradasi Mineral Batuan Oleh Asam-Asam Organik.Jurnal Ilmu Tanah dan Lingkungan. Vol 5 (1) p: 1-17

Mirzah, 1990.Pengaruh Tingkat Penggunaan Tepung Limbah Udang yang Diolah Dalam Ransum Terhadap Performans Ayam Pedaging. Tesis Pasca Sarjana Universitas Padjajaran.

Mirzah, Yumaihana dan Filawati.2008. Pemakaian Tepung Limbah Udang hasil Olahan Sebagai Pengganti
Tepung Ikan Dalam Ransum Ayam Broiler. Makalah Ilmiah. Fakultas Peternakan, Universitas Adalas Padang.

Muzzarelli, R.A.A and P.P. Joles. 2000. Chitin and Chitinases; Biochemistry of Chitinase. Switzerland, Bikhauser Verlag.

Nwanna, L.C. 2003. Nutritional Value and Digestibility of Fermented Shrimp Head Waste Meal by African Catfish Clarias gariepinus. Pakistan J. Nutr., 2 (6): 339-345

Poedjiadi, A. 2010.Dasar-Dasar Biokimia Edisi Revisi. UI Press. Jakarta.

Purwaningsih, S., 2000. Teknologi Pembekuan Udang. Penebar Swadaya, Jakarta

Purwanti, E., Sukarsono, and Zaenab.2001. Teknologi Pemanfaatan Limbah Pengolahan Udang dengan Metode Destilasi. Jurnal Ilmiah Dedikasi. Mei 2003 Vol 1. No. 1

Santoso J., Nurjanah dan Irawan. 2007. Kandungan Kelarutan Mineral Pada Cumi Cumi Loligo Sp dan Udang Vannaemi Litopenaeus vannamei. Jurnal Ilmu-Ilmu Perairan Indonesia. Vol 15 No. 1 (2008)

Sediaoetama A.D. 1993.Ilmu Gizi untuk Masyarakat dan Profesi di Indonesia. Dian Rakyat. Jakarta 
Stell, R. G. D. dan J. H. Torrie. 1995.

Prinsip dan Prosedur Statistika

Suatu Pendekatan Biometrik. PT

Gramedia Pustaka Utama, Jakarta.

Widodo, W. 2000. Bahan Pakan Unggas

Non Konvensional. Universitas

Muhammadiyah Malang.

Winarno F.G. 2008.Kimia Pangan dan

Gizi. Mbrio Press. Bogor. 
Nilai Protein Kasar, Kalsium dan Fosfor Tepung Limbah Udang

\begin{tabular}{cccc}
\hline Perlakuan & Protein Kasar $(\%)$ & Kalsium $(\%)$ & Fosfor $(\%)$ \\
\hline A0U1 & 44.76 & 4.95 & 1.51 \\
A0U2 & 43.80 & 4.11 & 1,76 \\
A0U3 & 43.33 & 4.04 & 1.67 \\
A0U4 & 44.28 & 4.94 & 1.51 \\
A1U1 & 54.81 & 3.54 & 1.03 \\
A1U2 & 54.52 & 3.17 & 1.07 \\
A1U3 & 54.60 & 3.91 & 1.19 \\
A1U4 & 54.51 & 3.67 & 1.27 \\
A2U1 & 58.01 & 3.20 & 0.97 \\
A2U2 & 58.46 & 2.22 & 0.88 \\
A2U3 & 58.55 & 2.85 & 0.97 \\
A2U4 & 58.45 & 3.65 & 0.90 \\
A3U1 & 56.23 & 2.51 & 0.85 \\
A3U2 & 56.32 & 1.88 & 0,64 \\
A3U3 & 56.14 & 2.96 & 0.53 \\
A3U4 & 56.77 & 2.07 & 0.52 \\
\hline
\end{tabular}

Tabel 1. Nilai protein kasar tepung limbah udang

\begin{tabular}{|c|c|c|c|c|c|c|}
\hline \multirow[t]{2}{*}{ Perlakuan } & \multicolumn{4}{|c|}{ Ulangan (\%) } & \multirow[t]{2}{*}{ Total } & \multirow[t]{2}{*}{ Rataan } \\
\hline & 1 & 2 & 3 & 4 & & \\
\hline A0 & 44.76 & 43.80 & 43.33 & 44.28 & 176.17 & 44.04 \\
\hline A1 & 54.81 & 54.52 & 54.60 & 54.51 & 218.44 & 54.61 \\
\hline A2 & 58.01 & 58.46 & 58.55 & 58.45 & 233.47 & 58.37 \\
\hline A3 & 56.23 & 56.32 & 56.14 & 56.17 & 225.46 & 56.37 \\
\hline
\end{tabular}

Tabel 2. Nilai kalsium tepung limbah udang

\begin{tabular}{ccccccc}
\hline Perlakuan & \multicolumn{7}{c}{ Ulangan $(\%)$} & Total & Rataan \\
& 1 & 2 & 3 & 4 & & \\
\hline A0 & 4.95 & 4.11 & 4.04 & 4.94 & 18.04 & 4.51 \\
A1 & 3.54 & 3.17 & 3.91 & 3.67 & 14.29 & 3.57 \\
A2 & 3.20 & 2.22 & 2.85 & 3.65 & 11.92 & 2.98 \\
A3 & 2.51 & 1.88 & 2.96 & 2.07 & 9.43 & 2.36 \\
\hline
\end{tabular}

Tabel 3. Nilai fosfor tepung limbah udang

\begin{tabular}{ccccccc}
\hline Perlakuan & \multicolumn{7}{c}{ Ulangan $(\%)$} & Total & Rataan \\
& 1 & 2 & 3 & 4 & & \\
\hline A0 & 1.51 & 1.76 & 1.67 & 1.51 & 6.45 & 1.61 \\
A1 & 1.03 & 1.07 & 1.19 & 1.27 & 4.56 & 1.14 \\
A2 & 0.97 & 0.88 & 0.97 & 0.90 & 3.72 & 0.93 \\
A3 & 0.85 & 0.64 & 0.53 & 0.52 & 2.54 & 0.63 \\
\hline
\end{tabular}


Jurnal Zootek (“Zootrek” Journal ) Vol. 35 No. 1 : 1-9 (Januari 2015)

ISSN 0852 $-2626$ 